KENOSIS : JURNAL KAJIAN TEOLOGI

ISSN 2460-6901(Print), 2656-4483 (Online)

https://e-journal.iaknambon.ac.id/index.php/KNS

DOI: 10.37196/kenosis.v1i1.283

\title{
SPIRITUALITAS EKOFEMINIS-LITURGIS: \\ Mengupayakan Rekonstruksi Spiritualitas Dan Etika Di Tengah Persoalan Pencemaran Lingkungan Domestik
}

\section{Fiktor Jekson Banoet}

\author{
Gereja Masehi Injili di Timor (GMIT) \\ Universitas Kristen Duta Wacana \\ Jalan Dr. Wahidin Sudirohusodo No.5-25, Kotabaru, \\ Kec. Gondokusuman, Kota Yogyakarta, \\ Daerah Istimewa Yogyakarta 55224 \\ victorjekson92@gmail.com
}

\begin{abstract}
This article explains gender inequality that has emerged in the ecological crisis, particularly domestic environmental pollution. On the one hand, this injustice reduces nature and its sacredness and, at the same time, reduces women. Respond to this crisis is by constructing an eco-feminism-liturgical spirituality. I argue that the praxis of ecofeminism and liturgical spirituality leads to concerns about ecological justice and gender. Therefore, this paper shows a reconstructive effort on the idea of ecofeminist spirituality with liturgical theology regarding environmental pollution and gender-based injustice through a constructive theological method. The liturgy is explored to the point that it ultimately has an ecological, public, and domestic character. This reconstruction of the idea has three benefits. Firstly, presenting transexist and ecological images of the God of the Trinity and scrutinizing parental metaphors. Secondly, to emphasize spiritual praxis with emancipatory dimensions in the public and domestic spheres. It is thirdly, affirming the ecological role of women in one living system and opposing the paradigm pathos, ant(d)ropocentric and Cartesianism.
\end{abstract}

Keywords: domestic environmental pollution, women, praxis, ecofeminist-liturgical spirituality.

\begin{abstract}
Abstrak
Penelitian ini memberi penjelasan mengenai ketidakadilan gender yang muncul dalam krisis ekologi, khususnya pencemaran lingkungan domestik. Di satu sisi ketidakadilan tersebut
\end{abstract}


mereduksi alam beserta kesakralannya dan pada saat bersamaan mereduksi kaum perempuan. Usaha untuk merespons krisis tersebut ialah dengan mengonstruksi spiritualitas ekofeminisme-liturgis. Saya berpendapat bahwa spiritualitas tersebut sangat bersifat praksis dan mengarah pada keprihatinan keadilan ekologis dan gender. Karena itu, melalui metode teologi konstruktif, tulisan ini menunjukkan usaha rekonstruktif atas gagasan spiritualitas ekofeminis dengan teologi liturgis perihal pencemaran lingkungan hidup dan ketidakadilan berbasis gender. Liturgi digali sampai ke arti dasarnya memiliki sifat ekologis, publik dan domestik. Rekonstruksi gagasan dimaksud memiliki tiga manfaat. Pertama, menghadirkan gambaran transexist dan ekologis pada Allah Trinitas dan mengkritisi metafora parental. Kedua, untuk menegaskan praksis spiritual yang berdimensi emansipatoris di ranah publik dan domestik. Ketiga, menegaskan peran ekologis perempuan dalam satu sistem kehidupan dan menentang patos paradigma, ant(d)roposentris dan Cartesianisme.

Kata Kunci: Pencemaran lingkungan domestik, Perempuan, Praksis spiritualitas ekofeminisliturgis.

\section{PENDAHULUAN}

Ekofeminisme menjadi aliran pemikiran yang menandingi pemikiran spekulatif-dominatif yang diwariskan dari Cartesianisme. Cartesianisme merupakan kesadaran filosofis pencerahan yang merangsang epistemologi Barat untuk mengembangkan modernisme, yang di dalamnya terdapat paradigma mekanistikreduksionis dalam mendefinisikan diri manusia, laki-laki, sebagai pusat being. Definisi tersebut mengintegrasikan alam secara seragam ke dalam kategori kontrol dan pola hierarkis, karena manusia, khusus androsentrisme, yang dipandang sebagai satu-satunya makhluk berpikir yang unggul. ${ }^{1}$ Cartesianisme juga mendefinisikan relasi manusia dengan alam yang dianggap sebagai entitas mesin, materi rendahan demi kepentingan manusia dan tidak mengenal atau berbeda dari jiwa dan akal budi manusia (res cogitan, the thinking things). ${ }^{2}$ Terutama karena Cartesianisme secara sosio-historis membangkitkan sains positivis (sejak August Comte), yang juga dipakai sebagai kerangka berpikir ekonomi kapitalis dan produksi teknologi yang masif dalam mengeksploitasi alam, termasuk perempuan. ${ }^{3}$

Latar belakang singkat epistemologi ini disampaikan untuk memberi gambaran bahwa: Pertama, pada abad ini, apabila kerangka berpikir yang tidak mengindahkan bentuk penerapan konkret patut dicurigai sebagai kerangka berpikir yang merevitalisasi logika dominasi, warisan filsafat Pencerahan-Barat yang melulu 
mengejar being, logosentrisme dan atomistik, lalu cenderung mengabaikan doing. Kedua, abad ini membutuhkan banyak solusi berpikir paradigmatis dan praktis antara pikiran dan tindakan. Jadi, bisa dikatakan bahwa modernisme di abad ini semakin intensif menghasilkan banyak permasalahan sosial dan ekologis, di antaranya ialah pencemaran lingkungan. Berpilin dengan permasalahan sosio-ekologis, maka teologi yang sangat dibutuhkan saat ini ialah teologi yang memikirkan antara refleksi teoritis, pengalaman dan tawaran bentuk-bentuk moralitas konkret. Dengan menyampaikan itu, saya tidak bermaksud hanya mengkritisi bentuk sekuler-filosofis dan modernisme saja, sebab nyatanya agama Kristen dan agama besar lainnya (salvivic dan wisdomic religion), dalam membangun spiritualitas, juga etikanya, sejak dulu menyumbangkan akar persepsi yang cukup sama dalam mendegradasi lingkungan. ${ }^{4}$ Agama Kristen juga mesti memeriksa diri juga ihwal spiritualitas dan etikanya. ${ }^{5}$ Sebab itu, dalam perspektif Kristen dibutuhkan lebih dari sekadar kerangka pikir spiritualitas yang berbasis being (ontoteologi $i^{6}$ ), tetapi juga spiritualitas-praksisional.

Penelitian ini disusun dalam beberapa pokok pembahasan. Pertama, mengajukan metode penelitian dan rancangan pendekatan. Kedua, pembahasan yang dimulai dengan mendeskripsikan pencemaran lingkungan domestik dan tuduhan pencemaran pada perempuan, serta penilaian moral. Ketiga, mengonstruksikan perspektif teologi ekofeminisme dan liturgis. Keempat, kesimpulan.

\section{METODE PENELITIAN}

Tulisan ini memberi perhatian pada pertanyaan, bagaimana melalui metode teologi konstruktif dapat disusun ulang spiritualitas ekofeminis-liturgis? Lebih tepatnya, bagaimana memikirkan ekofeminisme Kristen yang dapat digali dari sumber-sumber teologi yang sudah ada dalam tradisi Kristen untuk direkonstruksi demi kepentingan merancang spiritualitas Kristen untuk merespons krisis ekologis tentang pencemaran lingkungan domestik? Karenanya, saya mengajukan kerangka pikir dengan memakai metode teologi konstruktif. Jason A. Wyman, Jr, mendefinisikan pendekatan teologi konstruktif sebagai, ${ }^{7}$

[A] method of doing Christian theology that takes seriously theological and church traditions as well as modern critiques of that tradition being something universal, eternal, or essential; it employs traditional themes and 
loci of theology in order to formulate useful, inclusive, fallible guidance for living as Christians in the contemporary world, against descriptions of a systematic theological system that pretend to unveil any true essence of essential reality of Christianity; and takes as it mode a goodfaith engagement with parallel academic disciplines, often religious studies; an activist/crisis confrontation; or, ideally, both.

Metode ini menghalalkan pendekatan sintesis, antara pelbagai tradisi teologis, disiplin ilmu dengan pelbagai diskursus. Karenanya, metode ini men-sintesakan teologi liturgi sebagai landasan refleksi ekologis dengan perspektif ekofeminis. Catatan saya untuk rancangan tersebut ialah: Pertama, agar tidak hantam kromo mengenai sumber teologi liturgi, saya membatasi pada isi teologi liturgi yang tidak menjurus pada rancang bangun liturgi sebagai tata ibadah. Kedua, saya memandang bahwa isi teologi liturgi akhir-akhir ini, di Indonesia, belum diramu sebagai pendasaran bagi ekoteologi Kristen. ${ }^{8}$ Kebanyakan refleksi teoritis ekoteologi-liturgis hanya jatuh pada bagaimana memandang unsur-unsur liturgi, yaitu simbol-simbolnya, seperti, air, tanah, pohon disiapkan tiap kali ingin menyusun liturgi dengan tajuk lingkungan hidup. Salah satu tulisan yang memunculkan hubungan ekologi dan liturgi, tetapi ditulis dalam rangka membuat tata ibadah, ialah karya Celia Deane-Drummon, Teologi dan Ekologi. ${ }^{9}$ Teologi liturgi adalah teologi yang merefleksikan tindakan liturgis Allah Trinitas dalam dunia, secara soteriologis, namun punya implikasi langsung dengan keutuhan ciptaan. Bertolak dari metode konstruktif, akhirnya harus diintegrasikan antara isi teologi liturgi dengan perspektif ekofeminis, yang memberi perhatian untuk merekonstruksi isi teologi liturgi trinitaris dengan elemen ekofeminisme dan lingkungan sebagai sumber spiritualitas merespons pencemaran limbah dan ketidakadilan gender di dalamnya.

\section{HASIL DAN PEMBAHASAN}

\section{Pencemaran Lingkungan Domestik}

Secara khusus, pencemaran lingkungan domestik yang diakibatkan manusia terjadi karena cara pandang antroposentrisnya dalam mendefinisikan limbah dan pencemaran. Sedangkan, alam tidak mengenal istilah sampah, yang ada hanyalah daur 
materi dan energi. Konsep sampah sendiri lahir saat terjadi interaksi antara aktivitas artifisial manusia dengan suatu proses alamiah oleh alam.

Umumnya, pencemaran limbah rumah tangga yang berbentuk padat disebut sampah padat (solid waste). Sebelum membahas sampah, maka perlu terlebih dahulu mendefinisikan limbah. Karena sampah hanya dapat dimengerti sebagai salah satu bentuk limbah. Limbah yang diartikan sebagai, "setiap bahan buangan aktivitas manusia yang berbentuk padat, cair atau gas yang tidak berguna bagi organisme atau ekosistem dan karena itu diperlukan pemikiran mengenai cara pembuangannya"10 terdiri dari tiga jenis, yaitu padat (juga setengah padat), cair, dan gas (atau juga radioaktif). Dari ketiga jenis limbah ini, maka yang disebut dengan sampah ialah limbah dengan keadaan padat. Jenis ini sering disebut juga limbah atau sampah padat. $^{11}$

Karena sampah padat adalah limbah, tentu pada hakikatnya memiliki sifat yang sama sebagai limbah, yaitu memiliki sifat destruktif, mengotori dan mencemar. ${ }^{12}$ Walaupun dianggap sudah tidak berguna dan tidak dikehendaki, namun bahan tersebut terkadang masih dapat dimanfaatkan kembali dan dijadikan bahan baku dalam kegiatan produksi lain. Untuk lebih memperoleh geneologi gambaran fisik limbah padat/sampah, maka saya mempersingkat penjelasannya hanya dengan memberi skema limbah dan sampah melalui bagan berikut ini: ${ }^{13}$

Gambar. Bagan. 1.

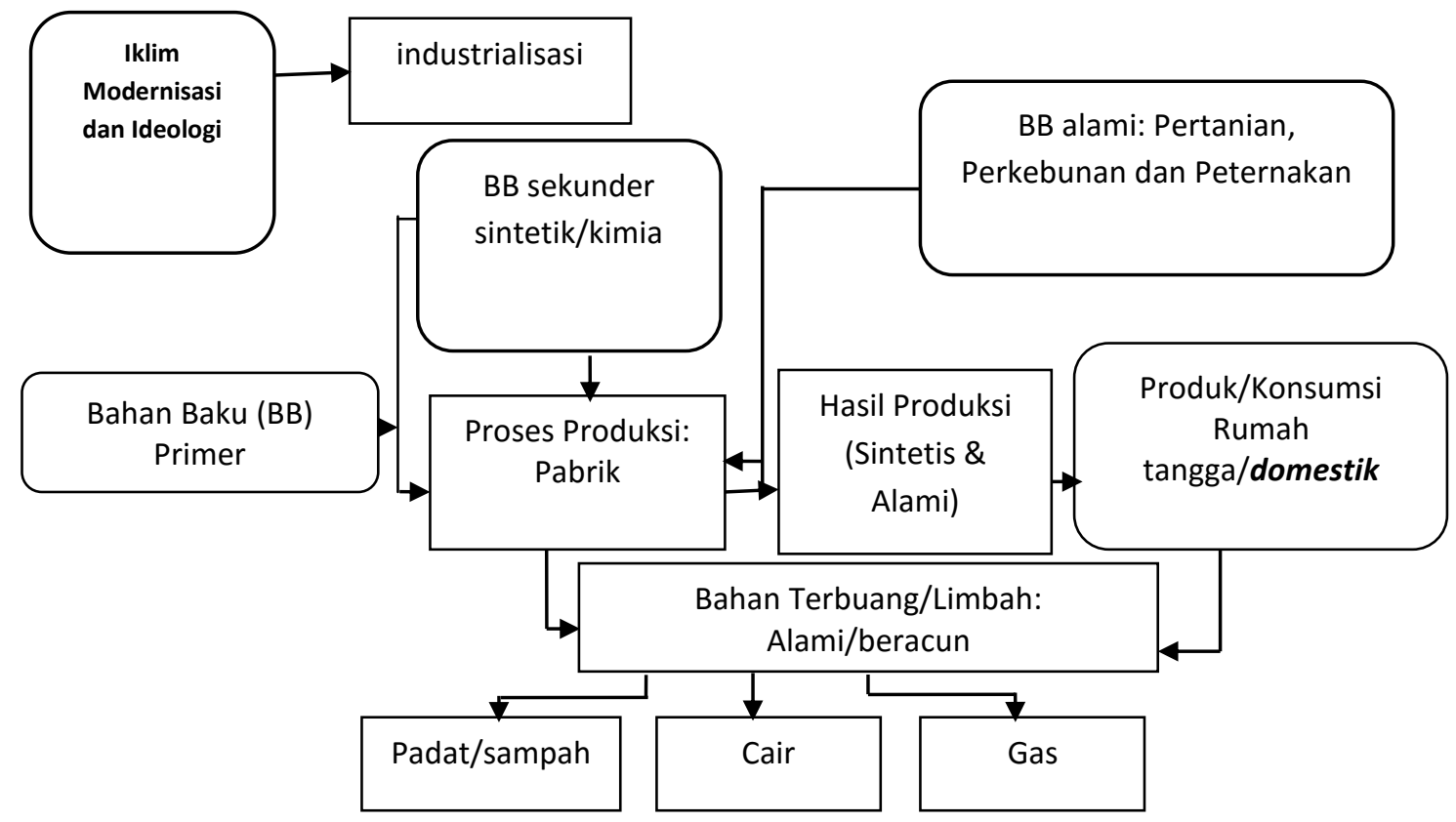


Dari bagan ini, sesungguhnya pencemaran lingkungan skala global sudah berlangsung pada aktivitas produksi di pabrik-pabrik. Namun, pada tingkat lokal, berlangsung di rumah tangga atau sampah domestik.

\section{Krisis Lingkungan Domestik dan Perempuan}

Dari deskripsi di atas, telah menjelaskan bahwa sampah padat domestik paling banyak dihasilkan dari aktivitas produksi dan konsumsi di rumah tangga. Maka, dapat dipahami bahwa tingkat pencemaran terbanyak suatu ruang perkotaan berdasarkan timbulan sampah merupakan hasil aktivitas kerumahtanggaan. Dari sudut ekofeminis, orang cenderung mempertanyakan secara etis bahwa siapakah yang paling dekat dengan aktivitas kerumahtanggaan, selain perempuan? Atau siapakah orang yang paling sensitif dengan urusan kerumahtanggaan? Pertanyaan konvensional ini, bisa berarti bahwa perempuan cenderung dituduhkan sebagai pihak yang berurusan dengan pemunculan timbulan sampah. Bahkan dalam aktivitas gandanya, khususnya seorang anak perempuan atau ibu rumah tangga, peran gandanya rentan dianggap identik dengan sampah itu sendiri. Perempuan diidentifikasikan dengan pencemaran.

Penilaian semacam ini berakar pada asumsi, bahwa perempuan memiliki wilayah privatnya di rumah atau dapur sebagai ruang produksinya. Sebaliknya, lakilaki di urusan publik. Mirisnya, penilaian konvensional ini, masih bertahan sampai sekarang. Dengan kata lain, secara negatif, dituduhkan bahwa perempuan adalah penyebab dominan pencemaran lingkungan domestik.

Pencemaran menurut kamus ekologi berarti "any damaging or unpleasant change in the environment that results from the physical, chemical, or biological side effects of human activities. Pollution can affect the atmosphere, rivers, seas, and the soil." ${ }^{\text {"14 }}$ Pencemaran juga berarti, bahan yang masuk ke lingkungan memiliki kecenderungan "discharge harmful substances in unusually high concentrations into the environment". ${ }^{15}$ Terkait hal ini, James A. Nash, sebagaimana yang dikutip Robert P. Borrong, menandaskan bahwa ${ }^{16}$

Polusi dapat dirumuskan sebagai akibat tindakan-tindakan manusia yang membahayakan dan fatal, langsung maupun tidak langsung, karena membuang unsur-unsur alamiah dan/ sintesis ke dalam ekosistem, yang tidak seharusnya dibuang atau karena yang dibuang jumlahnya melampaui kemampuan ekosistem berasimilasi secara normal. 
Berdasarkan definisi ini, pencemaran merupakan proses masuknya zat atau komponen asing yang tidak dikenal alam. Proses tersebut merupakan hasil dari proses produksi dan konsumsi manusia. Prinsip proses pencemaran tersebut ialah akumulatif. Semakin lama, semakin merusak. Jadi, tergantung daya kelola alam untuk menyerapnya atau justru, bila melebihi ambang batas kemampuan alam, tentu akan dientas kembali sebagai bencana bagi organisme lingkungan dan manusia.

Pencemaran ini kemudian berakibat pada: Kerusakan pada lingkungan tanah (litosfer), mencemari udara (atmosfer), merusak ekosistem air (hidrosfer), laut (oceanosfer), terganggunya perkembangan sosial dan kesehatan (sosiofer), memberi pengaruh buruk pada psikologi manusia dan kemanusiaannya (psikosfer). Semua sistem kehidupan memperoleh dampak dari pencemaran lingkungan.

Dengan demikian, dari sudut ekofeminis, tidak bisa dikatakan, bahwa ihwal pencemaran pada tingkat domestik, identik dengan perilaku perempuan, hanya karena ia lebih sensitif mengelola produksi rumah tangga. Penilaian tersebut menurut saya merupakan bentuk Cartesianisme etis. Cartesianisme berpikir mekanistik dan dualistik, memisahkan ruang aktivitas laki-laki dan perempuan, dan mengidentifikasikannya dengan aktivitas kerjanya. Jika perempuan hanya berada pada urusan domestik, maka pencemaran identik dengannya. Harusnya mengatakan, bahwa pencemaran merupakan ulah manusia (antropogenik). Semua manusia adalah pelaku pencemaran. Jadi, penilaian moral seperti ini, tentu berakar pada penilaian deep ecology (DE). Meskipun pada awal perkembangannya, ekofeminisme yang berakar pada aliran DE juga dibantah oleh kritik feminis Jym Cheny, karena masih bersifat androsentris dan netral gender. ${ }^{17}$ Dalam teori DE, penilaian moral tidak boleh menuduh satu elemen ekologis yang menyebabkan krisis lingkungan. Haruslah dinilai seimbang/holistik. ${ }^{18}$ Penilai berdasarkan perspektif androsentrisme ${ }^{19}$ adalah sebuah banalitas misoginisme, dan karenanya androsentrisme adalah sebuah Cartesianisme dan sebaliknya, Cartesianisme adalah androsentrisme. Begitu pula, jika ingin melakukan perbaikan, tidak bisa dituduhkan bahwa satu pihak saja yang menyebabkan suatu krisis lingkungan tertentu. Artinya, jika tekanan pencemaran pada androsentrisme, maka evaluasinya berdasarkan perspektif feminis harus jelas dan bertanggung jawab. 
Dari pertimbangan ekofeminis dan DE tadi, maka tidak bisa mengidentifikasikan perempuan dengan pencemaran. Di sisi lain, tampak bahwa memang pada hakikatnya, seperti perkataan Borrong, persoalan sampah merupakan persoalan moral, yakni bersinggungan dengan ketidakadilan. ${ }^{20}$ Dari sudut feminis, letak persoalan ketidakadilan tepat pada tuduhan feminisasi pencemaran, karena bersifat mengategorikan perempuan pada ruang privat rumah tangga, serta membagi pekerjaannya berdasarkan ketegori biologis dan seksual. Dalam analisis Talcot Parson, terkait dengan feminis Marxis, perempuan dipandang sebagai penunjang dan penanggungjawaban baik dan buruknya produksi, yang menentukan konsumsi, ${ }^{21}$ pembuangan dan pengelolaannya. Sedangkan laki-laki merupakan pihak yang memiliki produksi atau pemilik properti rumah tangga. Perempuan tidak memiliki nilai ekonomis. Ia hanya instrumen ekonomi. Baik-buruk penilaian pada perempuan, bergantung pada baik-buruknya produksi, konsumsi rumah tangga dan mekanisme pengelolaannya.

Di samping itu, perlu dicatat, bahwa pengelolaan rumah tangga dan pengelolaan limbah saja tidak mencukupi dalam menahan laju pencemaran domestik. Butuh lebih daripada itu, yakni rekonstruksi paradigma yang menopang perilaku atau moralitas dan etika, yang mesti dimunculkan dari spiritualitas. Sebab, asumsinya adalah: Pertama, krisis lingkungan (pencemaran) berakar pada krisis spiritualitas, paradigma moral dan etika. Kedua, moralitas dan etika hanya mungkin terbentuk jika seseorang memiliki persepsi dan spiritualitas yang ekologis. Spiritualitas dapat mengandaikan moralitas (meskipun keduanya berbeda). Karena pada dasarnya, manusia bukan hanya makhluk biologis dan ekologis, tetapi juga makhluk religius. Bahkan, "binatang spiritual dan metafisik."22

Di bawah ini, mengonstruksi spiritualitas yang berdimensi ekologis sebagaimana dimaksud sebagai spiritualitas Kristen, yang bukan saja merujuk pada basis sistem ajaran Kristen yang konvensional semata. Lantaran, sistem konvensional itu sendiri, selama ini tendensinya patriarkis (male-centered) dan telah dibuktikan memberi pengaruh opresif terhadap manusia dan alam (sexist religion). ${ }^{23}$ 


\section{Spiritualitas Ekofeminis-Liturgis}

Ekofeminisme adalah bagian dari gerakan feminisme, dan menjadi salah satu aliran besar dalam berekoteologi, di samping ekoteologi pembebasan, dan ekoteologi proses. ${ }^{24}$ Sebagai diskursus filosofis dan teologis, ekofeminisme memiliki banyak aliran yang saling mengeritik secara positif. ${ }^{25}$ Sebagai teori, ekofeminisme sejak abad ke-20 telah menjadi kerangka berpikir kritis dan konkret yang tidak lagi mengulangi kesalahan pemikiran Barat dan sekularismenya di Asia dalam memikirkan wacana krisis ekologis, meskipun saat ini banyak pandangan misoginis modern (antifeminisme dan post-feminisme) mengkritisinya sebagai "gerakan".

Pertama kali menemukan ekspresi mencolok pada tahun 1970-an, ekofeminisme menurut Sam Mickey, dimulai dengan berbagai upaya untuk mengembangkan teori dan metode untuk memahami dan menanggapi hubungan kompleks antara peran gender, tubuh yang dibedakan secara seksual, dan kehidupan, tanah, udara, dan air yang membentuk lingkungan alam. Menurut Mickey, ekofeminisme juga merupakan kritik langsung pada feminisme Barat, ${ }^{26}$

Focusing on intersections of humans and non-humans, ecofeminism thus stands in contrast to feminism, which views human issues in relative isolation from ecological concerns, and in contrast to ecological descriptions of non-human organisms and ecosystems. Ecofeminism accounts for the intimate intertwining of human and non-human ways of being. Accordingly, ecofeminists are often critical of the dualistic tendency to treat humans and non-humans as two mutually exclusive categories.

Ekofeminisme melampaui feminisme antroposentris dan androsentris. Sony Keraf mencatat, ekofeminis merupakan bentuk telaah etika ekologis yang ingin menggugat dan mendobrak cara pandang dominan (grand narrative) yang berlaku dalam masyarakat modern dan sekaligus menawarkan cara pandang baru, dan perilaku untuk membendung krisis ekologis. Jadi, Keraf memandang ekofeminis sebagai gerakan filosofis-moral. Di samping itu, ia juga memandang varian ekofeminis: liberal, marxis, sosial dan radikal, berdasarkan basisnya pada feminisme yang dikutip dari Alison Jaggar, Feminist Politics and Human Nature. Keraf memandang bahwa ekofeminis adalah aliran pemikiran atau teori yang subversif dan revolusioner. ${ }^{27}$ Subversif berarti bahwa ekofeminis merongrong, mengganggu dan menggugat cara pandang dan nilai yang berlaku konvensional dan diterima, yakni pandangan ekologis yang berakar pada patriarki. Revolusioner berarti, perubahan radikal terhadap cara pandang 
konvensional yang laten tersebut, terutama pandangan etika yang berbasis pada mentalitas laki-laki yang dominatif. Jadi, etika antroposentrisme seperti dimaksud di atas, sebenarnya merupakan etika yang didefinisikan dari perspektif androsentrisme. Dengan demikian, ekofeminis berarti teori subversif dan revolusioner terhadap dominasi androsentrisme.

Berbeda dengan Keraf yang condong pada etika, ekofeminis yang didefinisikan oleh Rosemarie Putnam Tong, lebih menekankan aspek krisis yang diakibatkan oleh sistem nir-etis yang diakibatkan oleh manusia. Tong memfokuskan bahwa krisis lingkungan adalah akibat dari opresi manusia, atau usaha manusia untuk mendominasi dunia non-manusia. Di samping itu, ia juga mengutip definisi Karen J.Warren, tentang ekofeminis, yang mengaitkan antara krisis ekologi dan obsesi dunia Barat, seperti epistemologi, keyakinan, nilai, sikap dan asumsi dasar yang dibentuk oleh konsep patriarki yang opresif. ${ }^{28}$ Opresi patriarkis itu punya rujukan pada dampak Cartesinisme seperti di atas. Konsep opresi tersebut adalah untuk membenarkan, menjelaskan dan menjaga hubungan antara dominasi terhadap alam dan subordinasi laki-laki terhadap perempuan.

Geneologi ciri pemikiran Barat yang patriarkis mengakibatkan krisis lingkungan terpola demikian: (1) Pola pikir berbasis nilai hierarkis, atas-bawah. Nilai terbesar dimiliki oleh pihak atas dan sebaliknya. Posisi atas adalah laki-laki dan sebaliknya. (2) Dualisme nilai. Pasangan berbeda nilai akan dipandang oposisi. Nilai tertinggi/transendental itu ialah pikiran, nalar yang dimiliki laki-laki. Sedangkan, nilai imanensi atau ketubuhan, materi, perasaan ialah milik perempuan. (3) Logika dominasi, yakni struktur argumentasi membenarkan subordinasi. Dominator ialah laki-laki, sedangkan subordinator ialah perempuan. Jika alur berpikir ini diterapkan pada alam dan perempuan, maka dalam logika dominasi, laki-laki berkuasa atas dunia perempuan dan alam. Mereka (perempuan dan alam) dinilai sebagai faktor instrumental yang dapat dieksploitasi. Dalam pola tadi dapat berarti bahwa perempuan direifikasi (diperbendakan) secara mekanistik-reduksionis. Bertolak dari pola tersebut, maka gerakan ekofeminis berarti refleksi kritis dan praksis-liberasi bertolak dari pengalaman opresif patriarkat-androsentris terhadap alam dan perempuan dalam aspek epistemologi, politik, ekonomi dan kebudayaan, demi terbentuknya relasi baru 
antar ciptaan yang berkeadilan. Dalam arti ini, perempuan mengidentifikasi pengalaman penderitaannya sebagai sebagai penderitaan alam dan sebaliknya. ${ }^{29}$ Hematnya, gerakan teoritis-kritis ini menentang dominasi androsentrisme terhadap ciptaan dan budaya. Secara teologis, refleksi kita akan bertolak dari pengalaman ke sumber-sumber teologi, kearifan kuno, Alkitab dan tradisi Kristen yang (mesti) direkonstruksi. Karenanya, saya akan menggali kearifan kuno dari istilah Yunani dari liturgi dan tradisi Kristen yang telah mengontekstualisasikan istilah liturgi.

\section{(Eko)Teologi-Liturgis}

Adolf Adam, membagi dua bentuk studi liturgi, yang ia pandang sebagai liturgical science, yaitu mempelajari liturgi dan merayakannya. Dalam tulisan ini, saya cenderung mendahulukan yang pertama sebagai dasar teoritis dan yang kedua dipakai sebagai dasar praksisnya. Bentuk dari sains ini, Adams petakan dalam pemeriksaan historis liturgi, struktur esensial, dampak dan manifestasi liturgi, terutama praksis liturgi (performs liturgical action). ${ }^{30}$ Dari petakan ini, maka sains liturgi dapat dikembangkan dengan berbagai studi teologi lainnya (intra/lintas disiplin). ${ }^{31}$

Martasudjita memandang bahwa sains liturgi bukan hanya suatu penjelasan akan sejarah dan makna upacaranya, melainkan suatu refleksi terhadap liturgi dalam rangka keseluruhan hidup kristiani, hakikat berimannya dan kebutuhan umat. Dalam sejarah, objek sains liturgi adalah gereja, yakni aktivitas ibadahnya. ${ }^{32}$ Namun, saya kira tidak cukup hanya mengurung obyek sains tersebut hanya dalam ibadah gereja. Tetapi dalam seluruh kehidupan manusia dan kebutuhan hidupnya. Artinya, saya berusaha mendaratkan obyek reflektif sains liturgi lebih pada isu-isu kontemporer, yakni krisis ekologis yang juga merupakan krisis terhadap perempuan.

Dari segi isi atau hakikat, teologi liturgi merupakan teologi yang memberi perhatian prinsipil pada usaha historis-konstruktif terhadap karya Allah di dalam dunia. Karenanya, pertama-tama bukan soal merancang bangun rumusan tata ibadah dan simbol-simbol perayaan liturgi dalam gedung ibadah. Tetapi menelaah sejarah dan uraian teologis tentang liturgi Trinitas sebagai subyek liturgi.

Kata liturgi diambil dari bahasa Yunani leitourgia (dalam bahasa Latin: liturgia) dengan kata kerjanya leitourgein. Kata leitourgia terbentuk dari dua akar kata 
yakni, ergon, yang berarti 'karya', dan leitos, yang merupakan kata sifat untuk kata benda laos, yaitu umat, bangsa atau rakyat. Secara harfiah, leitourgia berarti 'karya publik' atau 'pelayanan yang dibaktikan bagi kepentingan bangsa' dan bagi kepentingan hidup bersama banyak orang. Karya-karya dimaksud (leitourgia), dalam masyarakat Yunani kuno, misalnya, pelayanan publik tanpa pamrih atau mencari untung dengan pembayaran yang dianggap sesuai dengan jasa layanan seseorang atau suatu lembaga; sumbangan dari orang kaya bagi masyarakat miskin; dan termasuk pajak dan cukai yang diperuntukkan bagi masyarakat atau kepentingan negara (Rm $13: 6) .^{33}$

Jadi, liturgi sebagai istilah Yunani, yang menurut asal-usul sejarahnya adalah pekerjaan yang dilakukan oleh orang-orang bagi kepentingan orang lain dalam komunitas atau di luarnya. Dengan begitu menurut asal-usulnya, istilah leitourgia memiliki arti profan-politis-sekularis. Kata tersebut mengarah pada karya pelayanan nir-kultis. Namun, pada perjalanan sejarah, pada abad 4-2 SZB, tradisi Perjanjian Lama memakai istilah leitourgia (menurut terjemahan septuaginta dari kata Ibrani Abodah) dipakai untuk aktivitas ibadah di Bait Suci. Seterusnya, pada abad 2 ZB, pemakaian kata ini diambil alih dalam jemaat mula-mula untuk menunjuk pelayanan pekabaran Injil (Rm.15:16) dan pelayanan sosial mereka (Rm.15:27, Flp. 2:25, Flp. 2:30, Flp. 4:18). ${ }^{34}$ Kemudian, oleh gereja, isi teologis dari leitourgia ini dipakaikan pada Yesus, sebagai sebagai mediator Dei, menurut surat Ibrani (8:1-13, 9:15, 25-26, 28 dan 10:12). Itu sebabnya, definisi liturgi beralih menjadi perayaan (misteri) karya keselamatan Allah dalam Kristus, yang dilaksanakan oleh Yesus Kristus, Sang Imam Agung, bersama gereja-Nya di dalam ikatan Roh Kudus. ${ }^{35}$

Dalam definisi ini, termuat beberapa pokok dimensi teologis. Pertama, sebagai sains, liturgi mencakup keseluruhan aspek kehidupan. Kedua, perayaan liturgi merupakan buah karya Allah Tritunggal, Bapa, Yesus Kristus dan Roh Kudus. Ketiga, subyek pelaksana liturgi, ialah Kristus dan gereja dalam arti organis, umat yang berkumpul (ekklesia) maupun lembaga. Keempat, oleh karena dimensi soteriologis dari perayaan berlaku kosmik-liturgis, maka subyek perayaan juga bersifat kosmik, yaitu seluruh ciptaan merayakan karya keselamatan yang dialami dalam Yesus Kristus. Jadi, dari isi teologis memiliki dimensi ekologis-kosmologis, dan sosiologi- 
publik yang kuat, ketika dapat ditarik penghayatannya dari sudut konsep penebusan atau mediator Dei. Relasi antara Allah, kosmos dan manusia adalah antarsubyek.

Dari sudut teologis, ekologi-liturgis harus dilihat dalam bingkai relasi antarciptaan yang setara, tidak hierakis dan dominatif. Karena hukum relasi terjalin secara teosentris, berpusat pada Allah Pencipta. Inilah titik hubung ekoteologi yang dapat dibangun. Liturgi memiliki jangkuan ekologis-kosmologis, sehingga bisa saja disebut ekoteologi-liturgis. Titik hubung ini memungkinkan pergeseran teori etika lingkungan yang ant(d)roposentrisme dan menjangkau unsur partisipasi semua ciptaan dalam relasinya, laki-laki, perempuan, dan semua unsur makhluk hidup non-manusia. Namun, bagaimanakah liturgi dapat dijangkau dari perspektif ekofeminis?

\section{Point of Contact: Depratriarisasi dan Rekonstruksi Metafora "Allah"}

Di atas telah ditekankan, bahwa pertama-tama, obyek refleksi liturgi adalah keseluruhan hidup manusia dan kebutuhannya, yang di antaranya ialah tentang krisis ekologis sebagai krisis terhadap perempuan. Kedua, refleksi liturgi ditekankan pada karya Allah Trinitas yang berdimensi ekologis dan antropologis. Namun, untuk menarik benang merahnya agar memperoleh refleksi spiritualitas ekofeminis berbasis teologi liturgis ialah pertama-tama merekonstruksi apa artinya Allah Trinitas dalam perspektif feminis. Karena Trinitas adalah subyek liturgi. Metafora dan simbolisasi Allah harus dide-patriarisasikan atau direkonstruksi lebih dahulu.

Dalam memberi respon terhadap Trinitas dari perspektif feminis, teolog pentolan Brazil, Leonardo Boff, menyatakan perlu dilihat dari perspektif paradoxal trans-sexist theology. Artinya, paham Allah Trinitas perlu direkonstruksi maknanya dimulai dari komunitas manusia. Trinitas tetap merupakan teologi Trinitarian klasik, namun rekonstruksinya mengangkat dimensi yang selama ini disuboordinasi, seperti dimensi feminin. ${ }^{36}$ Paham Allah Trinitas merangkum pengalaman manusia: laki-laki dan perempuan, serta segenap ciptaan. Dalam pengalaman manusia secara utuh, gambaran parental Allah bukan lagi hanya disebut 'Bapa.' Ia dapat direfleksikan sebagai Bapa yang ke-Ibu-an dan Ibu yang ke-Bapa-an. Dan untuk menggambarkan bahwa Ia adalah sumber kehidupan-kosmis, maka Ia disebut sebagai 'Allah-rahimi' Jadi, elemen yang terkandung dalam paham Allah Trinitas adalah feminin dan maskulin. Konsekuensinya, maka Yesus Kristus mesti dimaknai demikian, terkecuali 
Roh Kudus, yang secara linguistik sudah jelas berdimensi feminin. ${ }^{37}$ Gambaran parental-kosmologis ini (Bapa-Rahimi) lebih cocok bagi konteks di Asia dan negaranegara berkembang (bekas jajahan). ${ }^{38}$

Lebih tajam dari Boff, teolog feminis yang sebangsanya, Ivone Gebara, menyatakan bentuk rekonstruksi paham Allah Trinitas. Bagi Gebara, tidak mengapa jika paham Trinitas konvensional/ortodoks direkonstruksi. Konsep Trinitas itu sendiri dalam sejarahnya adalah hasil rekonstruksi manusia, khususnya laki-laki. Trinitas adalah pengungkapan ilahi simbolis yang manusia antropomorfisasikan sejak manusia membutuhkannya. Paling tidak itu dilakukan oleh leluhur dan dalam tradisi religius Kristen. Jadi, seketika, secara dinamis, kita dapat mengubah formula makna tersebut yang saat ini kita terima, jika muncul pandangan baru yang ingin kita konstruksikan. ${ }^{39}$ Gebara mengatakan, "kita sendirilah yang saat ini menerima satu hal dan besok kita memperbaiki apa yang telah kita katakan. Jika kita menerima gambaran Allah sebagai pelindung/pengayom atau sebagai sosok yang lembut dan berbelas kasih... kita bisa mengubah gambaran tersebut dengan membangun persepsi kita yang baru". ${ }^{40}$

Mengubah gambaran yang dimaksud Gebara, bukan dipahami secara radikal dengan membongkar semua fondasi Trinitas historis. Tetapi rekonstruksi atau pemulihan makna. Karena menurutnya, manusia adalah makhluk yang membutuhkan makna. Maka, makna Allah Trinitas dibutuhkan orang Kristen bukanlah Allah yang hanya sebagai Bapa, tetapi juga Ibu. Karena Trinitas adalah kata yang menunjuk pada pengalaman manusia, apa yang diketahui dan dihidupinya. Dalam rekonstruksi makna Trinitas inilah, Gebara bermaksud menjembatani makna sosio-demokratis dan pluralitas dalam Trinitas untuk merancang bangun spiritualitas ekologis. Spiritualitas ekologis tersebut diisi dengan ide ketubuhan yang biasa dipakai dalam ekofeminisme, seperti yang dimaksud Charlene Spretnak, bahwa ${ }^{41}$

para ekofeminis (walaupun tidak semuanya) yang tertarik pada gambaran dewi kerohanian yang lebih menghargai rasa berdasar-kodrat dari yang sakral sebagai yang imanen dalam Bumi, tubuh kita, dan seluruh komunitas kosmik daripada meletakkan di dalamnya suatu Allah-bapa yang jauh dari "keterlibatan" dengan (dunia) materi.

Ide ketubuhan atau lebih tepatnya ide imanensi, yaitu Allah Trinitas yang dipandang sebagai Allah panenteis, yang melampaui ontoteologi, lebih membumi. ${ }^{42}$ Ide ini juga 
dipakai Gebara dalam lima perspektif: ${ }^{43}$ Pertama, Allah dan kosmos. Di situ ia gambarkan bahwa alam raya dan isinya adalah ciptaan Allah, namun semuanya saling berelasi. Kedua, Trinitas di Bumi. Di situ ia katakan bahwa Bumi sebagai Trinitas, artinya berdimensi Trinitarian. Ketiga, Trinitas dalam persahabatan dengan umat manusia dan kebudayaan. Trinitas bersifat kosmis, maka kepelbagaian adalah bagian dari masyarakat alam semesta. Keempat, Trinitas dalam relasi manusia. Yang ditekankannya ialah saling memahami perbedaan dalam dialog yang setara. Karena yang berbeda itu merupakan kesatuan dalam Trinitas secara mistikal. Kelima, Trinitas dalam tiap manusia. Baginya, keberadaan pribadi kita sendiri bersifat Trinitarian.

Dari gagasan seperti ini, hubungan antara ekofeminis dan liturgi memperoleh tempatnya pada paham tentang Allah Trinitas yang dimaknai secara seimbang dan alam dipandang sakral dan dapat digenderisasi. ${ }^{44}$ Allah Trinitas yang dipandang sebagai subyek liturgi baru memperoleh tempat untuk berefleksi tentang krisis ekologi saat ada rekonstruksi makna. Makna yang direkonstruksi itu ialah yang tendensinya eko-androsentris menuju makna yang lebih eko-feminis. Alasannya bahwa rekonstruksi makna itu telah mengandaikan nilai-nilai ekososio-demokratis yang mengandaikan adanya dimensi ekologis dan antropologis, yang patut diakui antarmanusia dan manusia terhadap ciptaan lain. Saya dapat katakan, bahwa rekonstruksi tersebut juga merupakan rekonstruksi epistemologi Kristen kita. Apa yang hierarkis dari ajaran Trinitaris menjadi holistik, egalitarian, organis, biofilik dan kosmofilik/logis. ${ }^{45}$ Dimensi ekososio-demokratis tadi, dapat diinterpretasikan lebih lanjut dalam relasi moral yang mengandaikan nilai-nilai: keadilan, kesetaraan, pengakuan hak dan perbedaan latar belakang, antara laki-laki terhadap perempuan, antara manusia dengan alam. Perempuan dan laki-laki, serta alam memperoleh haknya secara moral, sebab manusia baru mendapat kembali makna dirinya dalam menata relasinya terhadap sesamanya dan terhadap alam dalam bingkai keyakinan akan Allah. Relasi tersebut ialah tanpa dominasi, eksploitasi, opresi, hegemoni, rasisme, seksisme, sebagaimana menjadi keprihatinan dalam ekofeminisme. Relasi yang tidak antroposentris dan androsentris tetapi teosentris.

\section{Spiritualitas dan Praksis Ekofeminis-Liturgis: Ekologis dan Publik}


Telah dikatakan sebelumnya, bahwa pencemaran memiliki dampak buruk bagi manusia dan lingkungannya. Kendati demikian, mengelola limbah pencemar dibutuhkan bukan sekadar perspektif bagaimana mengelolanya, tetapi mengelola dasar perilaku manusia. Pengelolaan itu dapat dilakukan, apabila seseorang ditopang oleh bentuk spiritualitas yang mengasumsikan moralitas. ${ }^{46}$ Dengan kata lain, perlu ditekankan bagaimana spiritualitas itu terbentuk dari memahami dan mengalami sistem kepercayaannya yang nota bene berbasis pada paham Allah Trinitas. Serta pengalaman perempuan sebagai kriteria spiritualitas. Dalam paham tersebut, menurut perspektif ekofeminis-liturgis, telah diupayakan pergeseran paradigma metaforisnya bahwa Trinitas konvensional di Asia, mesti dimaknai secara baru secara trans-sexist, 'Allah-rahimi', yang diambil dari gambaran parental-kosmologis. Meskipun kelihatan paradoxal,namun begitulah metafora. Para teolog eko-feminis memandang bahwa pergeseran ini perlu, namun setiap perubahan metafora janganlah diabsolutasikan dan diidolatrikan, supaya para teolog eko-feminis juga tidak jatuh pada kesalahan yang sama dengan menganggap bahwa Allah hanya dapat disapa dengan metafora feminin, 'Ibu', sebagaimana konstruksi patriarki-androsentris, menyapanya hanya sebagai 'Bapa'.

Karena itu, makna yang dapat ditarik untuk spiritualitas perlu seimbang, dan bukan lagi tendensi androsentris-patriarkis, bahkan kiriarki, yang jika dihayati dapat berimplikasi pada pembentukan paradigma moral yang hierarkis dan destruktif, khususnya terhadap perempuan dalam konteks pencemaran limbah padat domestik. Maka, dengan menambahkan atau memunculkan elemen feminin, tentu menolong kekristenan untuk lebih menghayati Allah yang justru lebih memberi pemaknaan tentang kesetaraan dan antidominasi di ranah domestik dan publik. Di situlah tepatnya, spiritualitas yang liturgis.

Dengan spiritualitas ini, orang Kristen lalu diberi orientasi baru pada penghayatan yang banter terhadap alam dan perempuan, dalam komunitasnya. Di satu sisi, moralitasnya dibentuk atau dilatih untuk memandang alam dan sesama sebagai subyek, bahkan "Yang-Lain". Penilaian moralnya terhadap krisis lingkungan bukan untuk mencari siapa penyebab krisis lingkungan, atau dengan menuduh pihak tertentu, melainkan mencari cara bersama untuk mengelola lingkungan yang tercemar dengan 
lebih progresif. Etikanya bukan lagi antroposentris, melainkan teosentris, yaitu etikanya tidak berpusat pada dirinya. Manusia, khususnya laki-laki tidak perlu memandang dirinya sebagai tujuan dari nilai dan norma-norma moral. Sebab, etika ant(d)roposentris, tendensinya memandang alam sebagai obyek dan tidak masuk jangkauan moralitas. Relasi dengan alam hanya terjadi secara instrumentalistik, sejauh menguntungkan kepentingan manusia, laki-laki. Karena itu, terbuka bagi eksploitasi dan destruksi. Etika ini sangat egois. Di samping itu, alam tidak dipandang bernilai pada dirinya, seperti halnya manusia. Manusialah yang menjadi tujuan etika karena menganggap hanya manusia laki-lakilah makhuk rasional (cartesianisme etis).

Dalam spiritualitas ekofeminis-liturgis, laki-laki, perempuan dan alam adalah komunitas biologis dan ekologis mesti berelasi secara demokratis: tidak ada yang superior satu sama lain - dalam ketegangan relasi dengan Allah. Alam dipandang bebas dari bias gender. Karena pada dasarnya alam, menurut spiritualitas ekofeminisliturgis berdimensi trinitaris.

Hematnya, melalui spiritualitas yang berbasis pada liturgi, pada akhirnya mesti menggerakan manusia, untuk pro-keadilan: terhadap pengalaman perempuan dan alam. Khususnya melakukan hal-hal konkret, seperti pengelolaan limbah dengan benar. Minimal dimulai dari dalam rumah sendiri. Mengikutsertakan semua komponen rumah tangga dan masyarakat di ruang publik. Karena dari spiritualitas liturgi, yang ditekankan adalah kepedulian (ethics of care), tindakan nyata atau praksis ekologis sebagai sebuah karya ekologis, publik, dan domestik.

\section{KESIMPULAN}

Berdasarkan uraian ini, isu ekologis ihwal pencemaran akibat limbah domestik, tidak cukup ditanggulangi secara teknis, hanya berdasarkan kategori pengelolaan lingkungan (seperti 4R: Reduce, Reuse, Recycling, Replace dan pengolahan composting). Karena itu saja tidak menjawab persoalan mendasar krisis lingkungan, yakni krisis spiritualitas, paradigma dan etika, terutama karakter. Itu sebabnya, dari perspektif ekofeminis Kristen, menawarkan paradigma dan spiritualitas yang berbasis pada teologi liturgi. Pertama, rekonstruksi metafora parental mengenai Allah dibubuhi juga dengan metafora yang berdimensi ekologis. Kedua, hal yang paling mendasar dari liturgi adalah menyumbangkan paradigma baru tentang 
mendefinisikan manusia, etikanya dan lebih khusus penghayatan tentang 'Allah rahimi', yang merupakan subyek liturgi, sehingga pada akhirnya, spiritualitas ini membentuk cara pandang yang baru tentang relasi dan praksis moralitas (yang menolak cartesianisme sebagai androsentris) dalam melakukan berbagai etika konkret di tingkat lokal: publik dan domestik. Itulah arah dari spiritualitas ekofeminis-liturgi.

Jadi, sifat liturgisnya adalah ekososio-demokratis: ekologis, kepublikan dan domestik. Ide ini bisa berujung pada aspek teologi publik. Sebab mengingat istilah arkais leitourgia dalam konteks Yunani adalah istilah publik: ergon-leitos/laos (karyaumat, bangsa, milik rakyat). ${ }^{47}$ Ini berarti sifat liturgi pertama sekali adalah publik, bukan kultus (sakral). Aksi mendahului kultus. Tetapi juga kultus yang menunjukkan aksi (praksis). Apa yang dilakukan untuk kebaikan dalam komunitas tersebut, seperti disampaikan oleh Putnam Tong, adalah politik kehidupan sehari-hari. ${ }^{48}$ Politik ini sejalan dengan arti akhaik leitourgia, yakni spiritualitas pelayanan publik dan juga domestik tanpa pamrih untuk merayakan kehidupan bersama. Liturgi pada akhirnya menunjukkan aspek keadilan ekologis dan gender.

\section{Endnotes:}

\footnotetext{
${ }^{1}$ Vandana Shiva and Maria Mies, Ecofeminism: Perspektif Gerakan Pempuan dan Lingkungan, trans. Kelik Ismunanto (Yogyakarta: IRE Press, 2005), 27-30. Reduksionisme memandang bahwa manusia sebagai satu-satunya "mesin" berpikir dominatif yang berada pada puncak tatanan kehidupan untuk menentukan (determinisme) segala keberadaan lainnya di alam semesta. Segala sesuatu diintegrasikan ke dalam kehendak berpikir manusia yang obyektif dan seragam. Jika reduksionisme dijalankan dalam ekonomi yang semata-mata mengejar penumpukan profit dan tidak berkelanjutan, maka segala sesuatu hanya dinilai berguna sejauh ia mendatangkan profit.

2 Sony A. Keraf, Filsafat Lingkungan Hidup: Alam sebagai Sebuah Sistem Kehidupan (Yogyakarta: Kanisius, 2014), bab II, 53-68.

3 Lih. Keraf., 53-63; Bnd.. Agus Sugiyono, "Metodologi Ekonomi Positivisme," 2001, https://doi.org/10.13140/2.1.4065.9841.

${ }^{4}$ Todd LeVasseur, ed., Religion and Ecological Crisis: The "Lynn White Thesis" at Fifty, 1 [edition], Routledge Studies in Religion 50 (New York: Routledge, Taylor \& Francis Group, 2017), 8-9.

5 Bandingkan usulan rekonstruktif White pada bagian penutup tulisannya. Lynn White, "The Historical Roots of Our Ecologic Crisis," Science, New Series 155, no. 3767 (1967): 1203-7, http://www.jstor.org/stable/1720120.

${ }^{6}$ Alister E. McGrath, Christian Theology: An Introduction, 6 edition (Chichester, West Sussex ; Malden, MA: Wiley-Blackwell, 2010), 15, 30. Ontoteologi membangun imajinasi mengenai Allah yang beratribut moral yang melampaui kemewaktuan, tidak berubah, superlatif dalam berbagai kebajikan, maha tahu, maha berdaulat, sumber surplus maknawi dan berbagai kualitas-kualitas metaontologis lain yang dilekatkan pada Tuhan. Karenanya, ontoteologi selalu membahas pengetahuan tentang Allah yang ultimet. Menurut Alister McGrath kebutuhan percakapan ontoteologi dalam percakapan mengenai Allah dalam iman Kristen lahir dari situasi zaman pada masa gereja perdana berkembang dan
} 
bertumbuh sehingga diperlukan bahasa dan formulasi yang terpahami oleh orang-orang di zaman itu. Saat ini, diskursus ontoteologi dipikirkan ulang dari kritik postmodern karena dampaknya kurang efisien beririsan dengan realitas dan didominasi oleh bahasa teologis dogmatis. Bnd. Richard Kearney, Anatheism: Returning to God after God, Insurrections (New York: Columbia University Press, 2010), 72-73; Suarbudaya Rahadian, "Menghayati Kembali Iman Kristen Lewat Anateisme," Indonesian Journal of Theology 3, no. 2 (May 1, 2016): 135-55, https://doi.org/10.46567/ijt.v3i2.53.

${ }^{7}$ Jason A. Jr. Wyman, Constructing Constructive Theology: An Introductory Sketch (Fortress Press, 2017), 440.

${ }^{8}$ Ahli liturgi di STFT Jakarta, Rasid Rachman, berkomentar mengenai diskursus ekoteologi-liturgis dikonstruksi di Indonesia, bahwa "tema tersebut memang belum meriah di Indonesia". Wawancara mengenai ekoteologi dan hubungannya dengan liturgi, Rasid Rachman, Diskursus Ekoteologi-liturgis, Messenger Facebook, July 29, 2019.

${ }^{9}$ Celia Deane-Drummond, Teologi dan Ekologi (Jakarta: BPK Gunung Mulia, 2006), bab 6, 91-101.

10 Michael Allaby, Macmillan Dictionary of the Environment (London: Macmillan Education, Limited, 1994), 367.

${ }^{11}$ Alan Gilpin, Dictionary of Environmental Terms, First Edition (London: Routledge and Kegan Paul, 1976), 169.

${ }^{12}$ P. H Collin, Dictionary of Environment \& Ecology (London: Bloomsbury, 2011), 222. http://site.ebrary.com/id/10519652.

${ }^{13}$ Enri Damanhuri, Diktat Pengelolaan Sampah (Bandung: Penerbit ITB, 2001), 6.

14 Jill Bailey and Facts on File, Inc, eds., The Facts on File Dictionary of Ecology and the Environment (New York: Facts on File, 2004), 188.

${ }^{15}$ Collin, Dictionary of Environment \& Ecology, 166.

16 James Nash, "Loving Nature: Ecological Integrity and Christian Responsibility", dalam Borrong, Etika Bumi Baru, 85.

${ }^{17}$ George Sessions, ed., Deep Ecology for the Twenty-First Century, 1st ed (Boston: [New York, N.Y.]: Shambhala, 1995), 272.

${ }^{18}$ Sessions, ed., 18.

${ }^{19}$ Kamus teologi menjelaskan arti androsentrisme yang "refers to 'male centeredness'. It describes a pattern of thinking that assumes the characteristics of ruling men to be the norm for all humankind. It emerges in patriarchal societies in which pyramidal structures place certain ruling males in the dominant position and subordinates women, children, and certain groups of non-elite men who depart from the norm (see patriarchy)." Ian A. McFarland, ed., The Cambridge Dictionary of Christian Theology (Cambridge ; New York: Cambridge University Press, 2011), 13.

${ }^{20}$ Borrong, Etika bumi Baru, 122.

${ }^{21}$ Arief Budiman, Pembagian Kerja Secara Seksual: Sebuah Pembahasan Sosiologis tentang Peran Wanita di dalam Masyarakat (Jakarta: Penerbit PT Gramedia, 1985), 22.

${ }^{22}$ Fiktor Banoet, "Dialog Kemanusiaan: Mengupayakan Dialog antara Spiritualitas Trinitaris dengan Ateisme Spiritual ala André-Comte Sponville,” Indonesian Journal of Theology 8, no. 2 (December 31, 2020): 171-97, https://doi.org/10.46567/ijt.v8i2.160.

${ }^{23}$ Jan S. Aritonang, Teologi-Teologi Kontemporer (Jakarta: BPK Gunung Mulia, 2018), 302-303.

${ }^{24}$ Robert Patannang Borrong, "Kronik Ekoteologi: Berteologi Dalam Konteks Krisis Lingkungan," Jurnal Teologi STULOS, 2019, 28.

${ }^{25}$ Bhuvaneswari Vijayaraj, “A Comprehensive Study of Ecofeminism," The Anthropologist 30, no. 1 (October 3, 2017): 68-75, https://doi.org/10.1080/09720073.2017.1377862.; Comp. Mary Phillips and Nick Rumens, Contemporary Perspectives on Ecofeminism (New York: Routledge, 2015), 1-57.

${ }^{26}$ Sam Mickey and Douglas A. Vakoch, eds., preface to Women and Nature? Beyond Dualism in Gender, Body, and Environment, Routledge Environmental Humanities (Abingdon, Oxon ; New York, New York: Routledge, Taylor \& Francis Group, 2018), xviv-xxi.

${ }^{27}$ A. Sonny Keraf, Etika lingkungan hidup (Yogyakarta: Penerbit Buku Kompas, 2010), 123-142.

${ }^{28}$ Rosemarie Putnam Tong, Feminist Thought; Pengantar Paling Komprehensif Kepada Arus Utama Pemikiran Feminis, trans. Aquarini Priyatna Prabasmoro (Yogyakarta: Jalasutra, 1998), 359-404.

${ }^{29}$ Ariel Salleh, Vandana Shiva, and John Clark, Ecofeminism as Politics: Nature, Marx and the Postmodern, Second edition, this edition was published in 2017 (London: Zed Books, 2017), 48-50; Lih. Celia Deane-Drummond, Creation, dalam Susan Frank Parsons, ed., The Cambridge Companion to 
Feminist Theology, Cambridge Companions to Religion (Cambridge, UK; New York: Cambridge University Press, 2004), 190-191.

${ }^{30}$ Adolf Adam, Foundations of Liturgy: An Introduction to Its History and Practice (Collegeville, Minn: Liturgical Press, 1992), 4.

31 Emanuel Martasudjita, Pengantar Liturgi: Makna, Sejarah Dan Teologi Liturgi (Yogyakarta: Kanisius, 1999), 90-91.

${ }_{32}^{32}$ Martasudjita, 91.

33 Adam, Foundations of Liturgy, 3. Bnd. Martasudjita, Pengantar Liturgi: Makna, Sejarah Dan Teologi Liturgi, 15. Bnd. Rasid Rachman, Pembimbing ke dalam Sejarah Liturgi: (Jakarta: BPK Gunung Mulia, 2010).2-3.

${ }^{34}$ Bosco Da Cunha and O. Carm, Teologi Liturgi dalam Hidup Gereja (Malang: Dioma, 2004), 16. Bnd. Martasudjita, Pengantar Liturgi: Makna, Sejarah Dan Teologi Liturgi, 15-16. Pemberian makna kultis dibuat oleh Kelompok Septuaginta (LXX), abad ke-3.

${ }^{35}$ Martasudjita, Pengantar Liturgi: Makna, Sejarah dan Teologi Liturgi, 27. Bnd. Adam, Foundations of Liturgy, 8-9.

${ }^{36}$ Leonardo Boff, Trinity and Society, trans. Paul Burns, Reprint edition (Maryknoll, NY: Orbis Books, 1988), 120-22. Bnd. Ivone Gebara, Longing for Running Water: Ecofeminism and Liberation, 1st Edition edition (Minneapolis, MN: Fortress Press, 1999), 147.

${ }^{37}$ Janet Martin Soskice, "Trinity and Feminism", in Parsons, The Cambridge Companion to Feminist Theology, 142-144. Roh Kudus dilihat sebagai 'ibu'.

${ }^{38}$ Aritonang, Teologi-Teologi Kontemporer, Lih. Bab 16, Teologi Feminis, 312. Sallie MacFague berpendapat bahwa semua bentuk rekonstruksi simbolis mengenai Allah memang terbatas. Namun, untuk konteks Barat, metafora yang cocok adalah bahwa Allah disapa sebagai 'sahabat', dengan mengasumsikan bahwa metafor tersebut lebih kepublikan, karena di Barat, perhatian parental anakorangtua telah luntur, dibanding gambaran parental di Asia yang masih kuat dan penting. Walaupun kemudian, metafora ini juga terbatas, karena belum merangkum hal ekologis.

39 Rosemary Radford Ruether, ed., Women Healing Earth: Third World Women on Ecology, Feminism, and Religion (Maryknoll, N.Y: Orbis Books, 1996), 15.

${ }^{40}$ Gebara, Longing for Running Water, 142.

${ }^{41}$ Charlene Spretnak, "Sumbangan Kritis dan Konstruktif Eko-Feminisme”, dalam Mary Evelyn Tucker \& John A. Grim, Agama Filsafat,dan Lingkungan Hidup (Yogyakarta: Penerbit Kansius, 2003), 235-236.

${ }^{42}$ Rosemary Radford Ruether, Goddesses and the Divine Feminine: A Western Religious History (Berkeley, Calif: University of California Press, 2005), 308.

${ }^{43}$ Gebara, Longing for Running Water,155-162. Bnd. Sallie McFague, Models of God, Theology for an Ecological, Nuclear Age, Underlining édition (Philadelphia: Augsburg Fortress, 1987), 69-73.

${ }^{44}$ Sejak lama orang Asia kebanyakan memandang alam secara gender. Dari pengalaman Asia Timur, perspektif Yin-Yang memandang langit dalam kategori maskulin, dan darat feminin. Sama halnya dengan pengalaman di Timor.

45 Janet Martin Soskice, "Trinity and Feminism", in Parsons, The Cambridge Companion to Feminist Theology, 138.

${ }^{46}$ Gretel Van Wieren, Restored to Earth: Christianity, Environmental Ethics, and Ecological Restoration (Washington, D.C: Georgetown University Press, 2013), 7.

${ }^{47}$ Adam, Foundations of Liturgy, 3.

${ }^{48}$ Tong, Feminist Thought; Pengantar Paling Komprehensif Kepada Arus Utama Pemikiran Feminis, 399.

\section{DAFTAR PUSTAKA}

Adam, Adolf. Foundations of Liturgy: An Introduction to Its History and Practice. Collegeville, Minn: Liturgical Press, 1992. 
Agus Sugiyono. "Metodologi Ekonomi Positivisme," 2001. https://doi.org/10.13140/2.1.4065.9841.

Allaby, Michael. Macmillan Dictionary of the Environment. London: Macmillan Education, $\quad$ Limited, 1994. https://public.ebookcentral.proquest.com/choice/publicfullrecord.aspx?p=5648 926.

Aritonang, Jan S. Teologi-Teologi Kontemporer. Jakarta: BPK Gunung Mulia, 2018.

Bailey, Jill, and Facts on File, Inc, eds. The Facts on File Dictionary of Ecology and the Environment. New York: Facts on File, 2004.

Banoet, Fiktor. "Dialog Kemanusiaan: Mengupayakan Dialog antara Spiritualitas Trinitaris dengan Ateisme Spiritual ala André-Comte Sponville.” Indonesian Journal of Theology 8, no. 2 (December 31, 2020): 171-97. https://doi.org/10.46567/ijt.v8i2.160.

Boff, Leonardo. Trinity and Society. Translated by Paul Burns. Reprint edition. Eugene, Ore.: Wipf and Stock, 2005.

Borrong, Robert P. Etika Bumi Baru: Akses Etika dalam Pengelolaan Lingkungan Hidup. Keempat. Jakarta: BPK Gunung Mulia, 2009.

Borrong, Robert Patannang. "KRONIK EKOTEOLOGI: BERTEOLOGI DALAM KONTEKS KRISIS LINGKUNGAN.” Jurnal Teologi STULOS, 2019, 28.

Budiman, Arief. Pembagian Kerja Secara Seksual: Sebuah Pembahasan Sosiologis tentang Peran Wanita di dalam Masyarakat. Jakarta: Penerbit PT Gramedia, 1985.

Collin, P. H. Dictionary of Environment \& Ecology. London: Bloomsbury, 2011. http://site.ebrary.com/id/10519652.

Da Cunha, Bosco, and O. Carm. Teologi Liturgi dalam Hidup Gereja. Malang: Dioma, 2004.

Damanhuri, Enri. Diktat Pengelolaan Sampah. Bandung: Penerbit ITB, 2001.

Deane-Drummond, Celia. Teologi dan Ekologi. Jakarta: BPK Gunung Mulia, 2006.

Gebara, Ivone. Longing for Running Water: Ecofeminism and Liberation. 1st Edition edition. Minneapolis, MN: Fortress Press, 1999. 
Gilpin, Alan. Dictionary of Environmental Terms. First Edition. London: Routledge and Kegan Paul, 1976.

Grim, Mary Evelyn Tucker \& John A. Agama Filsafat,Dan Lingkungan Hidup. Yogyakarta: Penerbit Kansiius, 2003.

Jr. Wyman, Jason A. Constructing Constructive Theology: An Introductory Sketch. Fortress Press, 2017.

Kearney, Richard. Anatheism: Returning to God after God. Insurrections. New York: Columbia University Press, 2010.

Keraf, A. Sonny. Etika lingkungan hidup. Yogyakarta: Penerbit Buku Kompas, 2010.

Keraf, Sony A. Filsafat Lingkungan Hidup: Alam Sebagai Sebuah Sistem Kehidupan. Yogyakarta: Kanisius, 2014.

LeVasseur, Todd, ed. Religion and Ecological Crisis: The "Lynn White Thesis" at Fifty. 1 [edition]. Routledge Studies in Religion 50. New York: Routledge, Taylor \& Francis Group, 2017.

Martasudjita, Emanuel. Pengantar Liturgi: Makna, Sejarah Dan Teologi Liturgi. Yogyakarta: Kanisius, 1999.

McFague, Sallie. Models of God, Theology for an Ecological, Nuclear Age. Underlining édition. Philadelphia: Augsburg Fortress, 1987.

McFarland, Ian A., ed. The Cambridge Dictionary of Christian Theology. Cambridge ; New York: Cambridge University Press, 2011.

McGrath, Alister E. Christian Theology: An Introduction. 6 edition. Chichester, West Sussex ; Malden, MA: Wiley-Blackwell, 2016.

Mickey, Sam, and Douglas A. Vakoch, eds. Women and Nature? Beyond Dualism in Gender, Body, and Environment. Routledge Environmental Humanities. Abingdon, Oxon; New York, New York: Routledge, Taylor \& Francis Group, 2018.

Parsons, Susan Frank, ed. The Cambridge Companion to Feminist Theology. Cambridge Companions to Religion. Cambridge, UK; New York: Cambridge University Press, 2002.

Phillips, Mary, and Nick Rumens. Contemporary Perspectives on Ecofeminism. New York: Routledge, 2015. 
Rachman, Rasid. Diskursus Ekoteologi-liturgis. Messenger Facebook, July 29, 2019. —.Pembimbing Ke Dalam Sejarah Liturgi. Jakarta: BPK Gunung Mulia, 2010.

Rahadian, Suarbudaya. "Menghayati Kembali Iman Kristen Lewat Anateisme." Indonesian Journal of Theology 3, no. 2 (May 1, 2016): 135-55. https://doi.org/10.46567/ijt.v3i2.53.

Ruether, Rosemary Radford. Goddesses and the Divine Feminine: A Western Religious History. Berkeley, Calif: University of California Press, 2005.

—, ed. Women Healing Earth: Third World Women on Ecology, Feminism, and Religion. Maryknoll, N.Y: Orbis Books, 1996.

Salleh, Ariel, Vandana Shiva, and John Clark. Ecofeminism as Politics: Nature, Marx and the Postmodern. Second edition, this Edition was published in 2017. London: Zed Books, 2017.

Sessions, George, ed. Deep Ecology for the Twenty-First Century. 1st ed. Boston: [New York, N.Y.]: Shambhala; Distributed in the United States by Random House, 1995.

Shiva, Vandana, and Maria Mies. Ecofeminism: Perspektif Gerakan Pempuan dan Lingkungan. Translated by Kelik Ismunanto. Yogyakarta: IRE Press, 2005.

Tong, Rosemarie Putnam. Feminist Thought; Pengantar Paling Komprehensif Kepada Arus Utama Pemikiran Feminis. Translated by Aquarini Priyatna Prabasmoro. Yogyakarta: Jalasutra, 1998.

Van Wieren, Gretel. Restored to Earth: Christianity, Environmental Ethics, and Ecological Restoration. Washington, D.C: Georgetown University Press, 2013.

Vijayaraj, Bhuvaneswari. "A Comprehensive Study of Ecofeminism." The Anthropologist 30, no. 1 (October 3, 2017): 68-75. https://doi.org/10.1080/09720073.2017.1377862.

White, Lynn. "The Historical Roots of Our Ecologic Crisis.” Science, New Series 155, no. 3767 (1967): 1203-7. http://www.jstor.org/stable/1720120. 